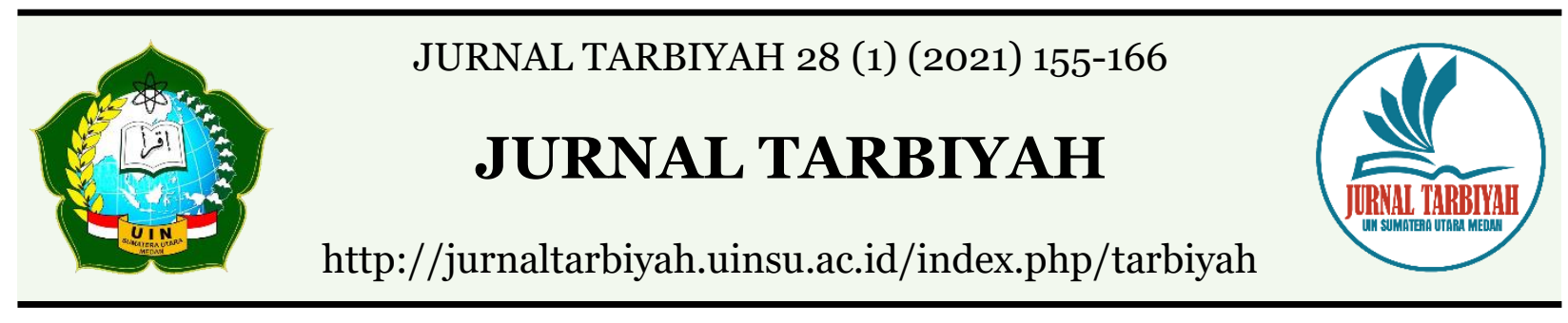

\title{
EFFORTS TO IMPROVE THE COMPETENCE OF STRENGTHENING TEACHER CAPACITY AND EDUCATION PERSONNEL THROUGH BINTEK IN SMA NEGERI 1 SERBA JADI
}

\author{
Budi Suhartono \\ State Islamic University of North Sumatera, Medan, Indonesia \\ Email: budisuhartono.tono@gmail.com
}

DOI : $10.30829 / \operatorname{tar} . v 28 i 1.984$

Accepted: March 17th, 2021. Approved: June 28th, 2021. Published: June 30th, 2021

\begin{abstract}
The purpose of this study was to determine the efforts in improving of teacher capacity and education personnel in SMAN 1 Medan, focus on the manufacture of Dupak, Piki and Bandicam. The method used and the reason for the variation of the phenomenological approach. The research method is how to do something by using a mind carefully to achieve the objectives in the study. The finding stated that the activities of making Dupak, Piki and Bandicam have benefits among the teachers
\end{abstract}

Keywords: Dupak, Piki, Bandicam 


\section{INTRODUCTION}

Teachers are people who play an important role in designing the learning strategies to be carried out (Ramayulia, 2018). The teacher as an educator should get training so that they can become active, creative and innovative. The competence of teachers in an educational institution need to be increased by their capabilities (empowering HR) are given training every year. According to Armstrong (2000: 198) put in his opinion that training is a well-integrated planned concept, careful, designed to produce an understanding needed to improve workers' performance. The objectives and benefits of this training are useful for increasing employee skills related to work to imcrease their performance by providing of the benefits to the progress of the institutional. When getting training should be closely related to the development competence that must be owned by the teacher. Development competencies consist f 5 (five) types of activities, namely: 1) Composing Scientific Writing (KTI), 2) Planning appropriate tekonology, 3) Make a Praga / Guidance tool, 4 ) Creating works of art and, 5) Following curriculum development activities. (M.Abdul Rozik, 2014: 19) The five development commission must continue to be trained and developed being a habit and create teachers who have good competencies. It implies that each teacher must have academic qualifications and competencies as learning (Ningrum 2016). Likewise the opinion of Erna Yayuk, et all, said it is very important to increase the quality of human resources, and can provide basic capabilities to children such as knowledge and skills (Erna Yayuk, 2017). From this opinion it can be described that the competence possessed by the teacher ranks the development of knowledge and skills for students .

The training has something to do with teacher competencies in carrying out their duties as educators, teachers and transfer skills. To get a professional teacher, the principal must schedule routine activities every 3 months as a training organizer and it is very important for schools, especially teachers. The program should be planned by the principal as part of the development of teacher competencies and continue to be echoed by the leadership of the institution. The teacher competency development program can be conducted by carrying out technical guidance for strengthening teacher capacity as an educator. According to Elfrianto, he said training is usually always handled by the term development. However, the development is more focused on increasing the ability in decision making and expanding human relations (human relations) for the upper level management and the management of the Level of Menenga, while training is intended for marawat at the lower level (Elfrianto: 2016: 46). 
The Principal submitted a program to fulfill the Head of the Sumatran Provincial Education Office C / Q, in providing of tutors to train in strengthening of teacher capabilities in high level. After being approved by the program, the guidance and technical guidance was strengthened by the educational personnel's teacher capabilities which was attended by all teachers who taught at Public High School 1 Multipurpose Subdistrict in Serba Regency Serdang Bedagai. The training held by schools and cooperated with the North Sumatra Provincial Education Office held a binteks for 3 days with a number of meetings of 24 hours or 3 days.

When bintek runs for 3 material days delivered by the expert who comes from the supervisor of the built school delivering 3 materials that must be understood by the participants, namely the teacher. The material discussed associated with the teacher's duty is about the manufacture of Dupak, Piki and the Republican Media (Bandicam). The material is very useful for teacher to complete the promotion / group to the upper level. Therefore the teacher must write scientific article. According to Bahdin and Ardial (2005: 149) say that this conceptual article basically aims to open discussion discourse, arguments, analysis, and synthesis of the opinions of experts or observations of certain fields. Thus, through the understanding articles such as the quotation above can be interpreted that the teacher must be able to write scientific papers.

\section{LITERATURE REVIEW}

1) Dupak Teacher

Ranking is one of the pride of teachers who have enough credit numbers, it can be increased by higher ranks than the old ones. When the teacher has been promoted, it means there is a progress in teacher career. According to Rivai 2003 in Hutasuhut 2014 said that career development is a process of increasing individual abilities in achieving the desired career. When a teacher has been promoted means that career development has been seen and will be different from friends who have not yet promoted.

Furthermore, it is said that when a teacher wants to be promoted, it must complete or fill the dupak (the list of proposals for determining credit numbers). Dupak was made per year after there was a new rule told and it was listed in Permendiknas number 35 of 2010 in Chapter VII Part B which read: The teacher is required to propose a credit rate assessment based on the results of the incession to the Principal / Madrasah every year based on physical evidence. Likewise, based on PAN \& RB Permenneg No. 16 of 2009 concerning Teacher's functional position and its credit number. 
In the dupak it consists of teacher activities; main elements and supporting elements. The main elements that can be rated are the following credit numbers: 1) Education, including: a. Formal education and obtain diplomas / degrees, and, B, participate in premaratical education and obtain a graduation and training letter (STTPP) preaching or certitude including induction programs. 2) Certain learning / guidance and tasks, including: a) carry out the learning process, for class teachers and subject matter teachers, b) implement the guidance process, for guidance and counseling teachers and, c) carry out other tasks that are relevant to the school / madrasah function, Sustainable Prophetic Development, Includes: A) Self-Development, B) Functional Training, and, C) Teacher Collective Activities that Increase Competence and / or Progrofesian Teachers.d) Scientific Publications: 1) Scientific Publications for Research Results or Innovative Ideas In the field of formal education, and, 2) Publication of textbooks, enrichment books and teacher guidelines, 3) innovative works, A. Finding appropriate technology, B. Finding / Creating Artwork, CMaking / Modifying Lessons / Tools / Props practicum and, d. Follow the development of standard drafting, guidelines, social and the like.

While the supporting elements assessed by their credit numbers, including: a) obtain a degree / diploma that it is not based on the fields that are required, b) obtained award / services and, c) carry out activities that support teacher tasks, including: 1) Guiding students in Real Practice / Practice of Industry / Extracurricular and the like.2) Become a Professional / Scouting Organization, 3) Become a Penilian Team Credit Rate, and, 4) Become Tutors / Trains / Instructors

By understanding the two elements, the assessment of credit figures, namely the supporting element and the main element. But when the field that not all teachers can calculate their own credit figures. It is understood that he has not understood the parts of the elements of the Penilian and who must be completed and strengthened. Even the field was found that the teacher had not been promoted for 5 years because he could not calculate his credit number. This is because there is an obstacle by the teacher faced. The obstacles faced by teachers include: 1) do not understand how to determine the credit number of each detail of teacher task activities (especially the credit figure element of learning and the main element of credit as a teacher who gets additional / particular tasks in school. 2) has not been able to compile points Credit into the format of the Dupak, 3) has not fulfilled the required terms of credit figures on the PKB element, and 4) do not understand the sequences of the preparation of physical evidence based on Dupak 
(Fauzan, 2020). The number of obstacles faced by the teacher so that the teacher who was promoted was finally looking for a jockey to do it.

Although it is understood when other people who work on teachers who often rely on other people's energy to make it sometimes do not rule out the possibility of mistakes and cause dishonesty in the preparation, which is important as long as the credit number is sufficient, it is not a problem for the teacher if he will pay a little to fulfill it.

Based on the observation, it can be found that teachers has difficulty composing Dupak for one year has carried out learning / guidance and carrying out certain tasks / additional schools. Implementation of PKB and teacher support activities. By understanding of teacher difficulties in making dupak preparation, the school needs to propose to the Education Office related to the rank of C / $Q$ to carry out bindek to strengthen the educator teacher capabilities, especially at the high school level.

The training / bintacy activity carried out trained the teachers to try to compile and calculate the credit figures obtained during one lesson. Through of the presence of tutors / speakers who become a signing and supervisor in the preparation of the dupak tested to all civil servant teachers, there will be a change set for the teacher. The training carried out by the administration of the Education Office in collaboration with the organizing school has been scheduled and regulated its implementation.

It is very excited when the implementation of training / bintask appears that several teachers ask a lot about how to compile and fill in credit numbers. The speakers who provide training to convey to all teachers that not all indicator column assessment columns are filled but only on the level of teachers

2) Piki (Publication of Inovation of Scientifik Works) Teacher

The manufacture of teacher picants is currently very low when found in the field. The cause of the low teacher to write piki is due to the low reading of the teacher. The lack of teacher reading power will have an impact to the low quality of education as in 2005 it was revealed that the quality of education in Indonesia was ranked 10 out of 14 developing countries in the Asia Pacific region. By understanding that Indonesia included ranked 1oth out of the Asia Pacific region, the government's task to strengthen teacher HR by holding training and seminars with the aim of increasing teacher competencies.

The teacher who has been understood their duties of educating, teaching and giving skills is not enough at this time but the teacher must be able to write the work he found in his daily activities. The writing skills must be owned by the teacher and need to be trained hardly o develop professional teacher. when the teacher has been trained to 
write scientific papers, he can submit a requirement for the next promotion. For example teachers who will rise groups from IV / A to IV / B, based on the decision to determine the functional position of teachers and their credit rates, and the decision with the Minister of Education and Culture and Head of Bakn Nomo 0433 / P / 1993, number 25 of 1993 concerning Directions for Implementation of Position, After understanding the regulation of the minister, all teachers must write scientific work.

Scientific works are defined as scientific papers which discuss one problem based on investigation, observations, data collection that can be obtained from a study, both field research, laboratory tests, or literature studies based on scientific scientific and thought (method) Empirical. (Wages, 2011: 1).

In general, scientific papers can be divided into two groups, namely: a) Scientific paper based on a report on the results of studies / research, and b) scientific papers in the form of reviews / scientific reviews / ideas. Furthermore, it is said that scientific papers can be presented in the form of research reports, scientific articles in journals, popular scientific articles in the mass media, seminar papers, books, dictates, modules and translation works.

There are several suggestions that need to be considered for teachers who want to write mass media, among others: 1 ) often study scientific writings and publishe in the mass media. Teachers should concentrate to the contents, systematics, pikic grooves of language style, themes, characteristics of articles in the intended media, 2) if possible to editors or people who have been able to write about the proper requirements of the intended media, 3) Expand insight In the field of education by reading, discussing, fulfilling the scientific forum or observing the phenomenon that occurs in the middle of the public, 4) Do not hesitate, bored, frustrating, when the article is rejected. Correction and language for causes as subsequent writing materials. 5) Start by writing in the mediathat is limited before writing on local or national level media. 6), Collect information about the method of writing, the terms of writing, writing criteria loaded, the themes of the writing required or prioritized the media we are headed. (Wages: 2011; 8-9). By understanding the rules of writing mass media, the teacher can develop the professional teacher. it can be done through various ways, one of them is to train the ability in scientific writing Andi Irwan et all (2019).

3) Learning Media (Bandicam)

When discussing of media in Arabic, the media is an intermediary or introduction to the message from the sender to the recipient of the message. Furthermore, it is said 
that learning is a planned business in manipulating learning resources so that the learning process is in the students. (Arief Sadiman, 2008: 7). The same thing is line to to Jamaluddin (2020) learning media is everything used to channel messages and can stimulate the minds, feelings, attention and willingness of students learn so that the accidental learning process can occur, aimed and controlled. Thus, it can be interpreted that learning media are tools or facilities that help the process of learning to be easier and more efficient. (Leni Indriani: 2019: 25).

Based on the results of research supported by various previous studies, including Herayanti \& Safitri (2019) Wulandari ET, AL, (2020), Panggabean (2020) stated that it turned out that Bandicam made online learning more effective. Cahyono (2020) also revealed in the results of his research that GRA's theory material turned out to be more effective when taught using the Bandicam application. According to Herayanti \& Safitri (2019) video technology gives convenience in learning. By using the Bandicam application a lot of convenience obtained by students when they follow the material that has been given by his teacher. For this reason, the teacher who provides subject matter in school should always prepare material by using the Bandicam application, it is more easily convey on teaching learning process. Professional teacher is important in the creation and application of the quality in learning process(Raden Roro Holy Nurdianti (2017).

\section{RESEARCH METHOD}

A. Approach the method used and the reason for the variation of the phenomological approach.

The research method is how to do something by using a carefully mind to achieve the objectives in research (Cholid Nar Narco, 2015). The method used by the author is a qualitative approach. Qualitative method is a method based on philosophy, postpositivism. This research is aimed to examine the natural object conditions (as opposed to experiments) where research is a key instrument, data analysis techniques are inductive / qualitative and the results of qualitative research emphasize the meaning of generalization.

Types and nature of research

A. Types of research

The type of research used is field research (Field Research) because this naturalistic research is carried out in natural conditions (natural settings). In this study 
the author described how the purchases of Dupak, Piki and Bandicam in improving the competence of the strengthening of the capacity of teachers and education force through bindek in all-round high school in the District of Serba, 2020/2021.

b. The nature of research

This research is qualitative as a research procedure that produces descriptive data in the form of written or oral words of people and the perpetrators observed. In this case the author describes how Dupak, Piki and Bandicam in increasing the competence of the strengthening of teacher capacity and education personnel through bindek in all-round high school in the District of Serba, 2020/2021.

The research location was conducted at Public High School 1 Multipurpose Subdistrict with the Sub-District of the Principal, Teacher.

Data collection technique

\section{A. Observation}

Observation instruments based on the guidelines, are commonly used in systematic observations where the observation actors work based on the guidelines which contain a list of types of activities that make it possible to observe the activities. (Sugiono, 2015)

Researchers made observations because the data that they want to obtain must use direct observations to the field to find out how Dupak, Piki and Bandicam in improving the competence of the strengthening of the capacity of teachers and educator through binding in all-round high school in the District of Serba, 2020/2021.

b. Interview

Interview (interview) researchers faced directly with respondents or subjects. The researcher asked something that had been planned to respondents. The results are recorded as important information in the study. In this study interviews were carried out directly to the parties related to the principal, the teacher of SMA Negeri 1 in the Serba District of Serba, the homeroom teacher and students. This study uses interviews to strengthen the results of research conducted.

c. Documentation

Another way to obtain data from respondents is to use the documentation technique. Documentation is a complement to the use of observation methods and interviews in qualitative research. The documentation obtained is in the form of records, transcripts, archives, and others in Public High School 1 in Serba Subdistrict, Serba District, Serdang Bedagai. 
Data analysis technique

The stages in data analysis, among them as follows:

1) Data collection

Data that was successfully collected through observation, interviews and documentation were recorded. The field note contains the right information in the field related to the manufacture of Dupak, Piki and Bandicam in increasing the competence of the strengthening of the capacity of the teacher and education staff through bindek in allround SMAN 1 in the District of Serba, 2020/2021.

2) data reduction

Data reduction is an activity summarizing field notes by choosing the main things and focused on important things related to the manufacture of Dupak, Piki and Bandicam in increasing the competence of the strengthening of the capacity of teachers and education staff through binding in all-round SMAN 1 Medan 2020/2021

3) Data Display

To make it easier to see the summary results, the authors present data by creating a table in data processing after describing the interview narration. In the pattern of the table shape it can be seen completely over the specific parts of the results of the study. On the basis of the pattern that appears on the data display, it can be drawn by conclusions so that the data collected has the meaning of Dupak, Piki and Bandicam in increasing the competence of the strengthening of the capacity of the teacher and education personnel through bindek in all-round SMAN 1 Medan SERBA District, 2020/2021.

\section{RESULTS}

The findings of efforts to improve the competence of teacher capacity and education staff in SMAN 1 Medan

a. Interviews with the Principal of Making Dupak, Piki and Bandicam

The principal supports the creation of the manufacture of Dupak, Piki and Bandicam. During this time the teacher when going up rank there is a team that works for making Dupak. So with this bindek there is a change in the teacher's paradigm in terms of making Dupak, Piki and the making of learning media through the Bandicam application.

b. The results of interviews with teachers about making Dupak, Piki and Bandicam

Our teachers are very happy with this bindek because as input on the addition of knowledge, especially about the material delivered by the speakers who provide training 


\section{c. Results of interviews with students about Bandicam}

It turns out that many wisms are contained when schools impose online learning. This is due to teachers who continue to strive to modify the learning methods performed. The latest method understood by students when the teacher gives material through Bandicam, it turns out that there are many benefits and conveniences that students have obtained.

Based on the results of interviews and supported by observation and observations, it turned out that Dupak, Piki and Bandicam brought many benefits, especially among Teachers as educators in SMAN 1 Medan. The teacher becomes more independent when it will propose a promotion thanks to the presence of bindek held at school and cooperates with the North Sumatra Provincial Education Office. The speakers present as tutors were very helpful in terms of implementation at the event. The material delivered so interesting makes us more open insight into our mind set as a teacher. Although it is understood that the dupak material in calculating it we have a lot of constraints but all that can be overcome. The obstacles faced by teachers include: 1) do not understand how to determine the credit number of each detail of teacher task activities (especially the credit figure element of learning and the main element of credit as a teacher who gets additional / particular tasks in school. 2) has not been able to compile points Credit in the format of the Dupak, 3) has not fulfilled the required terms of credit rates in the PKB element, and 4) do not understand the sequences of physical evidence based on Dupak (Fauzan, 2020)

Implementation of Bintek to increase the competence of the strengthening of the capacity of teachers and education force in SMA N 1 Medan in Serba Subdistrict, Serba. a. The results of interviews with the Principal of the Implementation of Bintek.

Bintek implementing activities have actually been programmed by the Principal because it has something to do with the use of BOS funds. In the BOS technical guidelines there is a charge of the existence of training that must be done to improve teacher competency in teaching and developing his knowledge. The implementation of the Bintek activity was held for 3 days by calculating 8 hours of face-to-face 2 days meaning 24 hours. The activity began on Thursday to Saturday.

b. The results of interviews with the homeroom teacher about the implementation of bindek about teacher competencies.

There are 4 teacher competencies that must be owned and understood by the teacher, namely 4, namely 1) Pedagogical Competence, 2) Personality Competence, 3) 
Professional Competence and 4) Social Competence. At the level of pedagogical competencies that must be mastered by the teacher is that the teacher is expected to be able to utilize information and communication media learning and teachers must be able to improve the quality of learning. Based on the competence, the teacher must continue to be given training, especially strengthening in its competence. It was strengthened by teachers and lecturers no. 14 of 2005.

c. The results of interviews with teachers about increasing the competence of teacher capacity strengthening

It has so that the teacher who transferred the science of drought is always equipped with qualified competencies so that they can move, creativ and always have innovation in developing knowledge especially for students. Without good competence it will not be possible for teachers to increase all the competencies they have. The competencies that are honed and developed capital to facilitate students to absorb knowledge will be taught by the teacher to him. The competence carried out by the teacher as proof of teacher work in accordance with Permendiknas number 35 of 2010 in Chapter VII Part B which reads: The teacher is required to propose a credit number assessment based on the results of performance assessment to the principal / madrasa every year based on physical evidence. Likewise, based on PAN \& RB Permenneg No. 16 of 2009 concerning Teacher's functional position and its credit number.

\section{CONCLUSION}

1. Efforts to improve the competence of teacher capacity and education Staffin SMA N 1 Medan, the District of Serba is conducted by following technical guidance which includes the manufacture of Dupak, Piki and Bandicam application.

2. Implementation of Bintek To Increase Competence Strengthening Teacher's Capacity and Education Workers at SMAN 1 Serba Subdistrict SERBA So, it is held at 3 days as a calculation of the Teacher Credit Rate as a Master's Competency Development Material.

\section{REFERENCES}

Andi Irwan Benardi, Haryanto, Sapton Putro 2019, Pelatihan Penulisan Publikasi Jurnal Ilmiah Terakreditasi Nasional Bagi Guru di MGMP Geografi SMA Kota Semarang, Jurnal Panjar Vo. 1 No 1 Februari 2019, 
Bahrdin, Nur Tanjung dan Ardial, Pedoman Penulisan Karya Ilmiah (Proposal, Skripsi, dan Tesis) Dan Mempersiapkan Diri Menjadi Penulis Artikel, Jakarta: Prenada Media

Elfrianto, Manajemen Pelatihan Sumber Daya Manusia Dalam Meningkatkan Mutu Luluasan, Jurnal Edutech Vol.2 No.2 September 2016.

Erna Yayuk, Arina Restian, Kuncahyono 2017, Analisis Kompetensi Guru di SDN Girimoyo 2 Kabupaten Malang, Jurnal Ilmiah Sekolah Dasar Vol.1 (4), 229-236.

Fauzan, 2020 Meningkatkan Kemampuan Guru Dalam Menyusun DUPAK secara mudah Dengan Menggunakan Apsena, Jurnal Pendidikan Sains, dan Humaniora, Vol 8 No. 2 April 2020.

Herayanti, L. \& Safitri B.R.A Pembelajaran Mendesain rumah Menggunakan Media Audio Visual Dengan Memanfaatkan Bandicam. Jurnal Pendidikan Fisika dan Teknologi, 5(2), 305, https: //doi.org/10.29303/jpft.v5i2.1429.

Leni Indriayani, 2019, Pemanfaatan Media pembelajaran Dalam Proses Belajar Untuk Meningkatkan Kemampuan Berfikir Kognitif Siswa, Prosiding Seminar Nasional Pendidikan, FKIP, Universitas Sultan Ageng Tirtayasa, Vol 2, No.1 2019.

M. Abdul Rozik 2014, Peningkatan Kemampuan Metodologi Penelitian Dalam Penulisan Karya Ilmiah Bagi Guru-Guru PKN MGMP PPKN SMP Se Kabupaten Tulungagung, Tulungangung, Jurnal Pengabdian Kepada Masyarakat, Vol.2 Nomor 1 Juli 2014. Ningrum, Komang Septia Cahya 2016, Pengaruh Kompetensi Guru Terhadap Kinerja Guru SMP Negeri 6 Singaraja, Jurnal Program Studi Pendidikan Ekonomi (JPEE) Volume 7 Nomor 2.

Rivai dalam Hutasuhut 2014 Pengembangan karir: career acceleration development program (CADP) pada PT PLN (Persero) distribusi Jawa Tengah dan DI Yogyakarta. http:// eprints.undip.ac.id/42834/1/HUTASUHUT.pdf. [5 Januari 2016].

Ramayulia 2018, Pengembangan Kompetensi Guru Dalam Pembelajaran, Jurnal Bidayah: Studi Ilmu-ilmu Keislaman, Vol. 9 No. 1 Juni 2018,77-87.

Raden Roro Suci Nurdianti 2017, Pengaruh Kompetensi Profesional Dan Kompetensi Pedagogik Terhadap Kinerja Guru Ekonomi SMA Negeri di Kota Bandung, Jurnal Ilmiah Manajemen \& Bisnis Vol. 18 No.2 2017,177-188.

Undang-Undang Republik Indonesia No 14 Tahun 2005 tentang Guru dan Dosen Wagiran, 2011,Pengembangan Profesi Guru Melalui Karya Tulis Ilmiah, Yogyakarta, PTK PPs UNY. 